\title{
Media presentation and public understanding of stem cells and stem cell research in Hungary
}

\author{
Lilla Vicsek* - Júlia Gergely
}

Institute of Sociology and Social Policy, Corvinus University of Budapest, Budapest, Hungary

Preprint version of article: Vicsek, Lilla - Gergely, Júlia (2011): Media presentation and public understanding of stem cells and stem cell research in Hungary, New Genetics and Society, 30 (1),1-26.

Available at: http://www.tandfonline.com/doi/abs/10.1080/14636778.2011.552297

\begin{abstract}
This paper reports on a research project which examined media coverage and audience perceptions of stem cells and stem cell research in Hungary, using focus groups and a media analysis. A background study was also conducted on the Hungarian legal, social and political situation linked to stem cell research, treatment and storage. Our data shows how stem cell research/treatments were framed by the focus group members in terms of medical results/cures and human interest stories - mirroring the dominant frames utilized by the Hungarian press. The spontaneous discourse on stem cells in the groups involved a non-political and non-controversial understanding - also echoing the dominant presentation of the media. Comparing our results with those of a UK study, we found that although there are some similarities, UK and Hungarian focus group participants framed the issue of stem cell research differently in many respects - and these differences often echoed the divergences of the media coverage in the two countries. We conclude by arguing against approaches which attribute only negligible influence to the media - especially in the case of complex scientific topics and when the dominant information source for the public is the media.
\end{abstract}

Key words: stem cell research, media influence, focus groups, Hungary

\section{Introduction}

There is a growing body of literature on stem cell related issues from a social scientific

perspective. A major issue within this literature is controversy and ethical dilemmas

surrounding the use of embryos. Many writings touch upon the public debates on embryonic

\footnotetext{
* Correspondence should be addressed to the first author: Lilla Vicsek, Institute of Sociology and Social Policy, Corvinus University of Budapest, Budapest, Közraktár u. 4-6., 1093. Hungary, telephone: + 36 1-482-7350, fax: +36 1-482-7348, e-mail: lilla.vicsek@unicorvinus.hu.
} 
stem cell research that have taken place in different societies such as the United States, the United Kingdom, Germany, Brazil, etc. Ethical controversies featured strongly in the stem cell related media coverage of these countries (Hughes et al. 2008, Jurberg et al. 2009, Kitzinger 2008a, Kitzinger and Williams 2005, Nisbet et al. 2003, Reis 2008, Weingart et al. 2008). In this paper we present our research results from a post-socialist society, Hungary, where in contrast, the issue of ethical concerns about the embryo - as we will demonstrate has been basically absent from the political sphere and where it has been only a marginal topic in the media.

The aim of our research was to study the role of the media in audience perception of stem cell research. We investigated the representation of stem cells in the Hungarian press and audience understandings of stem cell research in Hungary. We conducted an analysis of the press coverage (spanning the period between May 2006 and the end of October 2008) and carried out a focus group study (with seven focus groups held at the end of 2008). A background study was also conducted on the cultural, religious, political and legislative aspects of the Hungarian context linked to stem cells.

Media analyses linked to stem cells have often concentrated on stem cell research, or even more specifically on embryonic stem cell research (Augoustinos et al. 2009, Checar and Kitzinger 2007, Kitzinger 2008b, Kitzinger and Williams 2005, Nisbet et al. 2003, Reis 2008, Weingart et al. 2008, Williams et al. 2003) ${ }^{1}$. Contrary to these practices, in our news coverage study we held it important to analyze articles on stem cell treatments and stem cell storage banks as well, besides items covering stem cell research. The main rationale for this was that we found in our focus groups that group participants did not make a clear distinction between current standard treatments, experimental research and storing of umbilical cord stem cells. For these reasons, it was found useful to include all these stem cell related topics in the press analysis to get a more complete picture. 
One of the goals of our research project was to compare the observed results to the findings of a research previously conducted by Jenny Kitzinger, Emma Hughes and Graham Murdock in the UK (Hughes et al. 2008, Kitzinger 2008a) - especially to compare our results of the focus group component. In order to enable comparison, our research in many respects applied the methodology of the UK research - particularly our focus group component. The UK research project included an analysis of the UK media coverage of human genetic research, interviews with key players of the public debate on stem cell research and a focus group study on the audience perception of stem cell research. Their focus groups were conducted in 2004 and 2005, the press coverage was analyzed from January to June 2004.

Stem cell controversies linked to the embryo have received extensive media coverage in the UK (Williams et al. 2003). The Hughes et al. research found that in the period examined many of the stories about human genetics focused on breakthroughs in stem cell/human cloning and medical applications and implications. Human genetics was mainly depicted as "having benefits which outweigh the threats". Anti-embryonic stem cell research groups appeared in part of the coverage, but human genetics was still presented in the articles more in a positive light than for example GM related issues. In their interviews with representatives of organizations critical of embryonic stem cell research, they found that these interviewees were of the opinion that the media had "hyped" the benefits of embryo research (Hughes et al. 2008).

Within the focus groups of the UK research, participants' spontaneous discussions focused on the embryo, and political debate and controversy connected to embryonic stem cell research featured strongly in the discussions - even if the participants themselves were often in favor of such research and emphasized the benefits of the biotechnology. Research participants mainly relied on the media as an information source. News bulletins which resourced discussions were in some cases linked to famous people. For example stories of 
celebrities, politicians campaigning for or against embryonic stem cell research, or news on the initiative of Richard Branson to collect umbilical cord blood. Most participants were aware of the controversies surrounding stem cell research that were presented in the media and of the key figures of the debate that appeared in the media. The media did not give a high profile to nuanced criticisms of embryonic stem cell research, criticisms that were not based on an anti-abortion religious position - such as critique coming from the organization Human Genetics Alert. In the focus group discussions participants were unaware of such more nuanced criticisms (Kitzinger 2008a).

According to the researchers, their results illustrated in many ways the importance of the media in the construction of risks of stem cell research and other emerging technologies amongst the UK audience: the empirical data highlighted the relevance of the media in “furnishing people's general impressions of a topic, mapping out the key players and issues, introducing ideas about the main risks and benefits, structuring the debate, defining the 'pro' and 'anti' sides, presenting vivid and memorable images" (Hughes et al. 2008), and in “engaging people's imaginative identification (e.g. with suffering patients)" (Hughes et al. 2008).

\section{Methods}

Investigating the context: For the background study on the Hungarian context, we examined the home-pages of the Hungarian parliamentary political parties and of stem cell banks, studied the relevant laws and regulations, and examined the related social science literature. We also consulted with representatives of the stem cell banks and conducted expert interviews $^{2}$. 
Media analysis: Articles on stem cells that appeared in the five most-read national dailies between May 1, 2006 and October 30, 2008 were chosen for the media analysis. The sample consisted of 326 articles $^{3}$. The whole text of the articles was coded by two coders ${ }^{4}$ into a quantitative data analysis software (SPSS). The method applied was primarily quantitative content analysis. This was supplemented with some qualitative elements - based on a close reading of the coverage by the author of this article.

In order to provide a fuller picture of the nature of the coverage, the data on the distribution of the dominant stem cell related themes was supplemented with the analysis of other aspects. The nature of the press coverage is relevant also for our combined analysis of focus group results and representations of the press. Factors other than raw data on the distribution of the dominant themes can be relevant for our investigation of how the media influences public understandings of stem cells, as coverage can differ in, amongst other things, its accessibility and its capability to engage the public. Henderson and Kitzinger (1999) demonstrated in an empirical study for example the relevance of studying soft news and not just hard news.

The variables we applied for the quantitative content analysis are shown in Table 1.

Table 1. Variables of the quantitative content analysis

Table 1 about here

Our analysis of the media coverage took as basis some of the analytical aspects of the UK media research (Hughes et al. 2008), but we developed many other analytical dimensions specially for the Hungarian research as the focus of their media analysis was somewhat 
different (human genetics and not only stem cells, and within their analysis they concentrated on other dimensions such as the role of sci-fi, etc.).

Focus group study: Seven focus groups were conducted in October and November of 2008. Four took place in Budapest, three in other cities. The sampling strategy employed called for participants with a diversity of characteristics.

Table 2. Composition of the focus groups

Table 2 about here

The diverse groups consisted of strangers and were diverse with respect to occupation, economic status and to a certain degree with respect to age (25-60) and education. In these groups we aimed for the types of participants which were not covered by the other groups.

One of the criteria of recruitment was to exclude anyone who worked in the health care field, was a biologist, or studied in related areas. However, it turned out that two of the pensioners in the pensioners' club group were involved in selling nutritional supplements, amongst others stem cell capsules (which supposedly increase the number of stem cells). They even had an occasion at the pensioners' club, where someone from the company which distributed these capsules came and gave a lecture connected to these nutritional supplements. Furthermore, the two club members who sold these products had received brochures which touched on stem cells. Taking this into account it is even more interesting that as we will demonstrate, even in this group - where there was more knowledge about stem cell research than in many other groups - the embryo as source of stem cells was not mentioned until the moderator introduced it into the discussions. 
Average group size was 8 , there were in total 56 participants in the seven groups. They were asked about their associations of stem cell research, their knowledge, their sources of information, and their hopes and fears. All groups were moderated by the first author, Lilla Vicsek. Participants were sometimes given information in the groups by the moderator. However, the strategy was - similarly to the UK research of Hughes et al (Hughes et al. 2008, Kitzinger 2008a) - to first get the participants to discuss an issue and then only after it was talked about, give some minimal information if they were totally mistaken and the issue was important. This way we could analyze how the participants talked of an issue before and after receiving information. For example, as participants made basically no mention of embryos in the discussions (even when asked about sources of stem cells), after a while the moderator introduced the topic of embryo into the discussions.

Within the focus group analysis we use English names for the participants, which are not translations of the original Hungarian names in order to preserve confidentiality. In order to make comparisons possible, our focus group study in most respects applied the methodology of the UK research (Kitzinger 2008a). We were informed on the sampling strategy, questioning strategy, the guide, and the results of that research. We employed basically the same guide, had similar sampling strategy, had the same questioning strategy and most of our analytical aspects for the focus group component stemmed from that research.

\section{The Hungarian context}

Before we present results of the media analysis and audience perception study it is important to discuss the special features of the Hungarian context. 
Religious context: How the embryo is viewed is connected to religious systems and the positions the churches take on the issue. Stem cell research and its applications which involve embryos as source are more objectionable from the perspective of Christian religions than for example from the perspective of Asian religions (Glasner 2005). However, there is some difference within the various Christian religions, especially with respect to the attitude of the church. The Vatican takes the strongest stance in claims to protect the embryo (Prainsack 2006). Although within Hungary the Catholic Church is by far the largest denomination (in contrast to the UK), the Hungarian Catholic Church has not been actively campaigning against stem cell research ${ }^{5}$, and many Hungarians who belong to the Catholic Church are not devout (Hegedüs 2007, Tomka 1996).

Cultural context: Research shows that Hungarians have a material focus: they attribute less importance to post-material values (such as human rights, global warming, etc.) and have fewer fears connected to post-material risks than the citizens of many other countries (Karácsony 2001, Vicsek 2004). This is relevant for our research as concerns over biotechnology or abuse of embryos in embryonic stem cell research can be regarded as postmaterial worries.

Legislative context: In Hungary Sections 180-182 of Act CLIV of 1997 on Public Health deal with issues related to embryonic stem cell research. The Act deals with a wide range of issues affecting public health, touching among others on the research that can be conducted on embryos - which however play a role not only in the case of stem cell research. Doctors and researchers consider that the passages dealing with research on embryos are not sufficiently precise. To be on the safe side they interpret the law to mean that it is forbidden to create embryonic stem cells, but with the appropriate authorizations it is permitted to import stem cell lines created in other countries and conduct experiments on them. This is a half-way position found not only in Hungary: there are countries where it is permitted to obtain stem 
cells from embryos, while others forbid even research on already existing cell lines (created from embryos). There is no separate law in Hungary for the regulation of stem cell research or therapeutic procedures using stem cells; in most cases the competent national authority, namely the Medical Research Council (ETT), with authorization to regulate, adopts decisions on concrete issues. This body has the most important powers of authorization, regulation and decision-making.

Political context: The political palette of Hungary is rather wide, with liberal, socialist parties and conservative, right-wing parties all part of the political sphere. Looking concretely at the political context linked to stem cell research, we can state that within Hungary in the investigated period and before, there was basically never any public debate on stem cell research, it was never a relevant issue within the political sphere. No views on the subject were to be found on the websites of the parliamentary parties (which otherwise contain positions on various issues arising in different areas). This lack of comment was even true for the site of the Christian Democratic People's Party, which emphasized on its web-page classic Catholic political issues (opposition to the propagation of euthanasia, abortions, same-sex marriages, etc.) ${ }^{6}$. According to the experts we asked, no organizations, politicians or political parties had campaigned for or against embryonic stem cell research in Hungary in 2008 or before. This is in contrast to some other countries - for example the UK or the US - where embryonic stem cell research has been the subject of turbulent public debate (Williams et al. 2003).

There were other kinds of debate which received media and public attention linked to stem cells in Hungary: administrative conflict linked to umbilical cord blood stem cell storage in 2003, and controversies surrounding the stem cell capsule developed in Hungary. In 2008 the Hungarian Competition Authority imposed a fine on the distributors of the stem cell capsule because they were unable to prove conclusively the therapeutic effect of the capsule ${ }^{7}$. 
While on the national level there was no political debate related to stem cell research, on the European level there were serious disputes in connection with the 7th Research Framework Programme in 2006, principally over whether community research support can be given in the area of embryonic stem cell research - even with constraints (not for creation of embryos for research, etc.). Throughout the debate Hungary was one of the countries in favor.

Stem cell research, treatments, and stem cell banks in Hungary: Stem cell research is conducted in Hungary at several institutions. The majority of these utilize human adult stem cells as well as stem cells of animal origin. In the investigated period human embryonic stem cells were used only at the National Blood Provision Service (OVSZ). Human fetal stem cells have also been used in a few occasions for research purposes in Hungary.

At present adult stem cells are used for treatments in Hungary. Bone marrow transplants are carried out routinely in cases of hematopoietic malignancies and immune deficiency disorders in order to restore blood formation. For a long while only stem cells from bone marrow were used for bone marrow transplants, but recently this practice has been replaced in part by the use of umbilical cord stem cells. Embryonic stem cells may not be used for therapy in Hungary. Stem cell treatments organized within the country but administered abroad are advertised in a number of forums in Hungary. According to Dr. Balázs Sarkadi and the Medical Research Council these interventions are "quack treatments" lacking scientific confirmation. Dr. Sarkadi noted that they are typically available in countries that do not have strict regulation and as a consequence attempts are made in inadequately controlled clinics using unknown stem cells, unknown methods and treatments of unknown effect to treat insufficiently known diseases.

There are a number of stem cell banks in Hungary that store blood from umbilical cords, all are of private nature, and are not community stem cell banks. The rate of new parents choosing stem cell extraction from umbilical cord was estimated to be around 5 
percent before the economic crisis started in 2008. The rate is held to be even lower during the recession ${ }^{8}$. Stem cell storage is not offered routinely within the health care system, however the marketing of stem cell banks probably reaches many pregnant women. Stem cell banks place their advertisements in journals/web-sites which target pregnant women, disseminate brochures on their services at gynecological clinics, district nurses' waiting rooms, etc. Each pregnant woman gets a so called "starting pack" in Hungary from the district nurse containing, amongst other things, samples of products, expectant mothers' journals, and brochures. Stem cell banks either have a brochure in this pack or have large adverts in the journals of the pack. Their adverts can also be found in health related journals/web-sites.

In the above we discussed the Hungarian context linked to stem cells up to the end of 2008 - the time our focus groups were held. It is worth mentioning however, that later some changes did take place. In the late summer of 2009, there was a scandal which caused great uproar and which received a lot of media attention. A company was accused of administering illegal therapy in Hungary involving stem cells from aborted fetuses. The events mobilized a pro-life group to demonstrate. These events are, however, topics for further research - for this paper only events up to the end of 2008 are relevant.

\section{News coverage of stem cells}

\section{Stem cell themes}

Most articles in our sample fell into two categories with respect to the dominant stem cell theme that they contained: 1 . scientific, medical breakthrough/overview of the state of the art 
(37.7\% of the sample), and 2. human interest story on drama of non-famous patient $(30.1 \%$ of the sample). Other topics were discussed much less frequently.

Figure 1. Dominant themes in the articles linked to stem cells $(\mathrm{N}=326)$

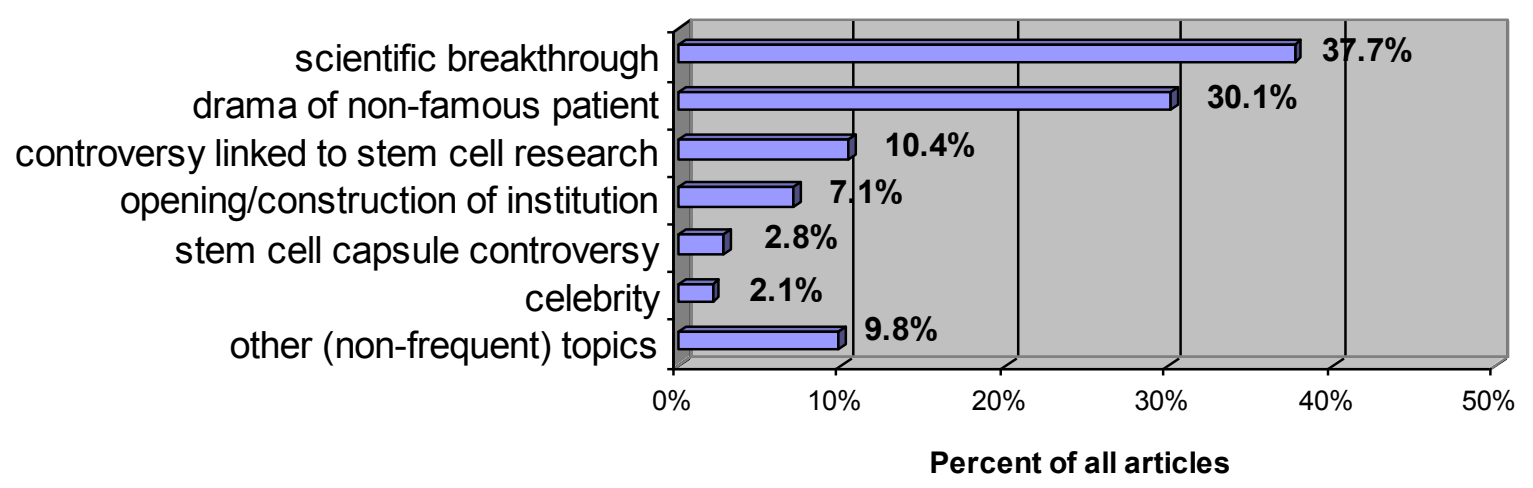

We discuss the two dominant frames ('scientific breakthrough' and 'drama of patient') in detail, as well as the third most frequent theme ('controversy'). We considered it important to analyze the later theme - even if it was present in much less articles than the two dominant themes - as it is a relevant element in our comparison with the UK.

Articles using the scientific breakthrough frame often gave the message that with the help of stem cell research serious illnesses would be most likely curable in the future. These news items typically did not discuss personal stories and did not have drama connected to concrete individuals. Within these writings in most cases it was foreign scientists or doctors who produced the 'breakthroughs'. The information density with respect to stem cells was high in these articles. 


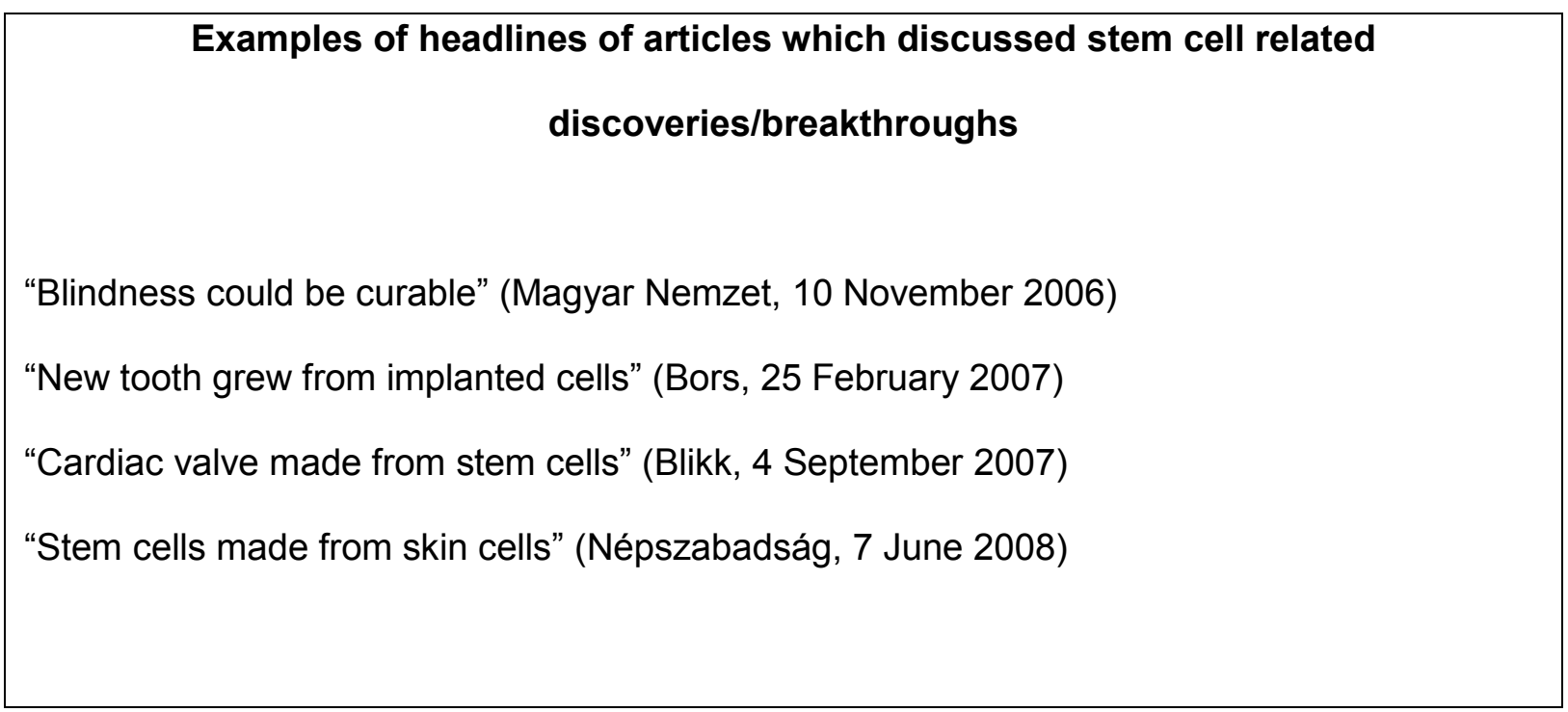

Within the human interest story frame on a drama of a non-famous patient, the most typical news item was a Hungarian patient going abroad/wanting to go abroad (mainly to China or Kiev) for stem cell treatment. The human drama in these cases centered usually on the one hand on the serious illness of the child (the patients in these cases were almost exclusively children) and the hardships their family faced because of it, and on the other hand on the high costs of the stem cell treatment, for which the family originally had no money, thus fund raising was/would be needed. In fact in many cases the fund-raising under way was the rationale for the article (and the readers were asked to contribute), or the articles were about the successful fund-raising. These articles underlined and reinforced the idea of stem cells leading to cures, even if they were often written in the fund-raising phase and not after all stem cell interventions were completed. The news items often focused on the perspective of the family involved, and for the family often stem cell treatment was seen as the only possible way for the patient to get better, high hopes were linked to the treatment. Moreover, even if articles rarely touched upon what happened to the patients after all of the treatments were completed, some did write about previous interventions with stem cells abroad causing an improvement in the medical condition of the patient. These articles were of a distinct genre, and contained similar narratives. Information linked to stem cells was typically limited 
as these articles centered more on the drama of the family than on the scientific elements.

Many of the articles employing this framing had a dramatic, emotionally charged style.

\section{Examples of headlines of articles which presented human interest stories linked to non-famous patients}

"Get better at last, my little boy!" (Blikk, 15 May 2006)

“We'll help, Anett!" (Bors, 19 August 2008)

"Concert for Evelyn" (Népszabadság, 19 January 2008)

"Oliver recovering in China" (Blikk, 28 August 2008)

Articles using the frame of political/ethical controversy about stem cell research, often mentioned generally that stem cell research was debated or opposed, or that it raised ethical problems without linking it to concrete actors. In the minority of cases, when either institutions or individuals were referred to within this frame, the most frequent references were to UK or US politicians (often Bush) or US celebrities, the Vatican/the Pope and the European Commission. The three events which were discussed most extensively within this frame were: Bush's veto of federal funding for embryonic stem cell research in 2006, the European Commission's decision on the funding of embryonic stem cell research belonging to 7 th Research Framework Programme in 2006, and the UK Parliament vote on hybrid embryos in 2008. The Hungarian political and civil sphere was basically missing from the articles, with only one or two references to Hungary's position on the FP7 research issue, but even here no Hungarian politicians were named. Often articles belonging to this frame made no mention of what stem cell research was, what it involved, or even quite what was held to be controversial about stem cell research. In two-thirds of these articles it is not even 
mentioned that it was embryonic stem cell research which the debate was about (even though the events covered in these reports were about the debate surrounding specifically embryonic stem cell research - only that was not mentioned in the article.). And even when the term ‘embryonic stem cell research' was employed, it was often not made clear that it involved taking stem cells from embryos.

\begin{tabular}{|l|}
\hline Examples of headlines of articles discussing political, ethical controversy \\
“Democrats win election” (Népszabadság, 9 November 2006) \\
"Pope criticizes Blair” (Magyar Nemzet, 25 June 2007) \\
"George W. Bush imposes first veto” (Magyar Nemzet, 20. July 2006) \\
\hline
\end{tabular}

Contrary to the two dominant frames, the majority of the articles which were categorized as discussing controversy on stem cell research touched on the topic of stem cells only as a very short part of the article, often only in one sentence $(42.4 \%$ of the articles belonging to this category discussed stem cell related issues in no more than one sentence). Only one article in our sample using the 'controversy' frame was on the front page, whereas front page positioning was more frequent in the case of the two dominant frames ('breakthrough' and 'patient story'). Moreover, if we look at the distribution of articles over time we see that close to two thirds of the articles of the controversy frame stem from the beginning part of the time span investigated, having appeared before the end of 2006, while this was true for only around one fourth of the articles belonging to the two dominant frames.

Although it is difficult to compare our results with those of other media analyses, as other research often concentrated on stem cell research/the stem cell debate and applied different coding, we can venture to suppose that ethical issues and debate regarding embryonic stem cell research was much less emphatic in the Hungarian media for the period 
examined than previous research reported for many other countries for certain time periods including the UK, US, Brazil or Germany (Hughes et al. 2008, Jurberg et al. 2009, Kitzinger and Williams 2005, Nisbet et al. 2003, Reis 2008, Weingart et al. 2008, Williams et al. 2003). According to expert opinions (Judit Cserepes, Balázs Sarkadi) not only within the time interval investigated by our press analysis, but even before that, ethical, political conflict connected to stem cell research was a neglected topic in the Hungarian media.

Data on the diffusion of the frames into press outlets show that the scientific breakthrough frame was present in both the political newspapers and the tabloids. The human interest frame appeared mainly - but not exclusively - in the tabloids, whilst the controversy frame was basically present only in the political papers, it was missing from the tabloids.

\section{Information about stem cells in the articles}

The majority of news items did not give information on the sources of stem cells. If such sources were mentioned, they were more likely to appear in hard news articles than in soft news articles.

Figure 2. Sources of stem cells mentioned in the articles $(\mathrm{N}=326)^{9}$ 


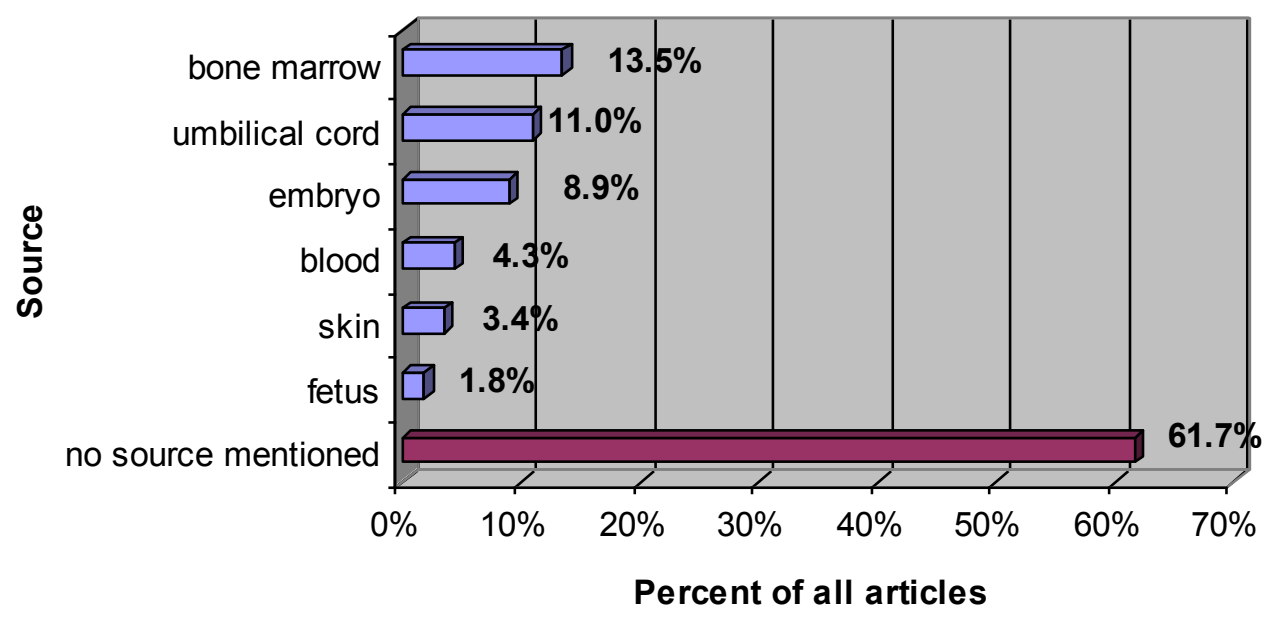

Embryo as source of stem cells was less frequently represented in the analyzed papers than other sources. Embryo was explicitly referred to in 8.9 percent of the articles as a source of stem cells, whilst adult stem cell sources were present in 34 percent of the writings.

The three sources of stem cells mentioned most often were bone marrow, umbilical cord and embryos ${ }^{10}$. While they were discussed in a similarly low quantity of articles (with embryo being the least frequently mentioned of the three sources), the nature of their coverage showed considerable differences. While some of the articles which mentioned umbilical cord and bone marrow were soft news articles, embryo as source was basically missing from soft news. Embryo, bone marrow and umbilical cord were each most frequently framed as breakthrough stories. However, whilst part of the articles touching on umbilical cord and bone marrow were writings about drama of human patients receiving stem cell treatment, basically none of the articles which featured embryos were human interest stories. This echoes therapeutic practice, as embryonic stem cells are not used in therapy, treatments in Hungary (and not used in many other countries either). Whilst almost one fifth of the writings about embryo as source discussed as major stem cell theme political-ethical controversy, basically none of the articles referring to bone marrow or umbilical cord were political controversy writings. This echoes the focus of the policy battles, as the political controversy articles dealt 
mainly with US and UK debate (if a location of the debate was given), and there the public debate with participation of politicians, scientists, etc. focused on embryonic stem cell research. Writings in which umbilical cord and bone marrow were referred to, were more likely to have appeared in the tabloids, than those which made mention of embryos. Articles which mentioned umbilical cord and bone marrow were more likely to have Hungarian relevance, while the majority of articles that write about embryo as source framed it as a foreign issue; most did not make any references (however small) to Hungarian characters or places. And if there was any Hungarian place or character in the article it was almost never in connection with the embryo, but with other topics, sources.

We checked whether several other kinds of information were present in the articles or not:

Table 3. Information on stem cells in the articles

Table 3. about here

All of the information we looked for was either discussed in only a small portion of the articles, or hardly present at all. It is also relevant to note that if something was coded under, for example, the category of regulation, it did not mean that the article contained a comprehensive, detailed presentation of regulation, only that the article gave any piece of information - however small - regarding regulation. An important aspect of the nature of coverage was that all of the kinds of information mentioned above appeared almost exclusively in hard news bulletins, and were predominantly in the political newspapers. 


\section{Audience perceptions of stem cell research}

\section{First associations with stem cell research}

Associations are useful as they can map out the field within which participants think of a topic. Associations do not have to be logical or based on sound knowledge, and can involve very vague recollections. All groups associated stem cells and stem cell research with cures. In every group, answers to the first question on what springs to their mind about stem cell research contained references to curing illnesses:

Emma: They use it to cure diseases.(Group 1)

Owen: Well, if I had to say something, therapeutic purpose, they cure with it, it can be used for different purposes. (Group 3)

Stem cell treatments in China came up in many groups, often connected to human interest stories:

Julia: I think stem cell therapy has something to do with the treatment of muscular dystrophy too. They even take young patients out to China. Or to Kiev.

Edward: I rather heard that it is China, and I think they do something in Russia too. I think that there .... that they do some kind of treatment with it there.

(several people speaking simultaneously)

Julia: Hopelessly sick people. And then you read in the paper that a foundation is collecting money for them [for the costs of treatment]. (Group 6)

In all groups sources of stem cells were mentioned during this first part of the discussion and umbilical cord was brought up as an association: 
Moderator: Let me ask, what is the first thing that comes to mind in connection with stem cells? If you hear stem cell research, what comes to mind?

Justin: Umbilical cord.

Moderator: Umbilical cord.

Justin: Yes.

Edward: Yes, an umbilical cord.

Jason: And its treatment.

Justin: Freezing it. They store it -

Colin: In liquid hydrogen.

Julia: It costs 300,000 Forints. I read about an extraction and storage like that. And later in adulthood it will be good for the person, or perhaps for his siblings too, good at some level because they have the same genes.

Nora: Yes, I believe they freeze it for the person's own use. And then they can use it later if the person becomes chronically ill. (Group 6)

Bone marrow was volunteered in many of the groups during first associations. Besides these there were some sources of stem cells which were referred to in one group each: thymus, fat tissue, tissue, teeth. None of the groups mentioned embryos - a finding which is in sharp contrast to the UK data (Kitzinger 2008a).

Stem cell treatments were constructed by many participants as a form of cure that is for the rich nations, for the very rich people and thus not for people such as themselves. High price of treatments was mentioned during first associations and referred to many times later in the discussions. This is in contrast to the UK groups, where the aspect of high expense of treatments was basically missing from the discussions.

Nora: What comes to mind is still that this is an expensive procedure, and expensive to store, that only the rich can afford it. And therefore they discriminate against people, or groups of people, because they can't afford it. (Group 6) John: I'm in favor, but I'm afraid that it won't reach the average person. (Group 7) 
Charles: But the reality is that they have to accept that in fifty years time it will be mainly the rich who can afford stem cells. (Group 2)

Stem cell capsules were discussed in some groups. Stem cell capsules were positioned by those in favor of them to be for ordinary people, whereas stem cell implantation was held by these research subjects to be for the rich, for the "millionaires". These participants placed their hope in stem cell capsules, arguing that these capsules had a lot of curing potential. One pensioner, Lucy (who was involved in selling stem cell capsules) spoke about the healing of her sister with the help of stem cell capsules. Her sister had cortical dystrophy, and could not talk, and with the help of these capsules allegedly she was able to talk again. However, controversy surrounding these stem cell capsules was mentioned by other participants in these groups, thus the alleged benefits offered by these capsules were not necessarily accepted by the others. In another group a participant recalled being solicited to become distributor of stem cell capsules - which he refused.

\section{Knowledge on stem cells and stem cell research}

It was known basically by everyone that there was such a thing as stem cell, stem cell research, and stem cell treatment. However, participants did not make a clear distinction between research, treatment and storage. Even if the questions pertained to stem cell research, answers often focused on treatments. Basically all participants had at least some knowledge 
on stem cells even if for some it was minimal, and there were huge gaps in most participants' knowledge. Still, the focus of the discussions in all groups was connected to stem cells.

Most participants did not know: i. whose stem cells could be used in the present or in the future for stem cell treatments (whether only one's own or not, etc.), ii. what the relationship between cloning and stem cell research was (or for some people: even if there was any relationship at all) or what therapeutic cloning was, iii. that embryos could be a source of stem cells, iv. that stem cells had different degrees of potency, v. that stem cell research was controversial, vi. how the research was regulated.

\section{Discussion on sources of stem cells in the groups}

Until the moderator asked on sources of stem cells, embryos were not mentioned in any of the groups. Associations with stem cell research, the first event heard of in connection with stem cell research, risks and benefits of stem cell research, past and future developments of stem cell research, were all topics which were discussed in the groups without any reference to embryos.

When the moderator asked participants about types/sources of stem cells mostly umbilical cord and bone marrow was mentioned as sources, with the odd references for example to teeth, pancreas, skin, placenta, muscle, blood, fat, organs (liver).

Moderator: And then my next question is, what kinds of stem cells have you heard about? (silence) If you have heard about any. If you haven't heard of any, then you haven't. So, you haven't heardNora: Just stem cell. Not any particular kind. Julia: Yes.

Nora: That kind from the umbilical cord. That's all. At least, I don't know what anyone else has heard. 
Edward: Yes. Um, well now, um, I heard about something now, because this bone marrow thing, that now it's, but whether that's stem cell or it's... (Group 6)

Only one person referred to the embryo as a source in answer to the moderator's question on types (David, a bank administrator whose highest educational level was college). However, there was a lot of confusion in this participant's understanding: it seems he did not necessarily think that stem cells are taken from the embryo even if stem cells were located there, and he said that there were no other kinds of stem cells. None of the other participants mentioned embryo when asked for sources, and no one volunteered the embryonic-adult stem cell differentiation.

Moderator: And what do you think, what kinds of stem cells are there?

(silence)

David: How do you mean, what kinds there are. A stem cell is a stem cell, it hasn't yet differentiated, so it's not tissue specific, that's what makes it a stem cell, it hasn't yet been decided at that stage whether it will become a nerve cell, a kidney cell, or a skin cell, or hair, or ..., it hasn't yet been decided. Differentiation begins at the end of the blastocyst stage, and that's after 26-28 divisions, so... (Group 5)

After the moderator told the participants that embryos can be a source of stem cells and asked them whether they have heard about it, most participants said that they had not. In several groups there were a few people who, when prompted, had a recollection of having heard about it before. But for most of these people it was a very vague recollection, and they hardly knew any information about it.

Those three research participants who besides knowing that embryos could be a source also knew a bit more about this, had all read more on stem cells because of particular personal motivation (e.g. two pensioners who made extra money selling stem cell capsules). It was striking that even these people did not bring in the topic of embryos earlier into the 
discussion. Thus, it seems knowledge about the existence of embryonic stem cell research and what they routinely associated with stem cell research were two different things for them. Their spontaneous discourse on stem cells and stem cell research was focused completely on non-embryonic sources.

\section{Discussion on embryonic stem cell research in the groups}

Participants were asked, among other things, about their knowledge of sources for embryonic stem cell research. As a consequence of their lack of knowledge, the answers given to this question were based on guesswork for all but one participant. In several of the groups aborted fetuses and IVF embryos were mentioned as a possible source (while, in fact, aborted fetuses are regarded by scientists as non-embryonic source). No one volunteered cloned embryos as a source of embryonic stem cell, and after the moderator told them about this, no one claimed to have heard about it before.

In several groups some participants imagined that embryonic stem cells are taken from within the uterus. In some of these cases it was thought that taking stem cells from the embryo/fetus caused it no harm, in other cases some potential harm was imagined:

Nora: And does it suffer harm or not?

Max: I don't think they do it like that.

Julia: They can only get it if they don't cause harm. The child that is born must be healthy. Nora: Yes, but...

Julia: But what's the guarantee of that, like everything in general, because we don't live in a world... 
Nora: Yes, but every such intervention causes harm. Because, for example, they take a sample of the amniotic fluid to screen for Down syndrome. And there too, they make the person sign a paper that there is a risk of, I don't know, say $10 \%$, of a spontaneous abortion. (Group 6)

In Group 7 several participants were of the view that the embryo died when the stem cells were extracted. When a participant heard this in the group she thought then that the embryos must be taken only from animals:

Mary: But, wait a minute. They're experimenting on people here? Because I don't believe that. I think these are still animal experiments. (Group 7)

Because of gaps in their knowledge participants could not imagine any scientific reason why embryonic stem cells could be preferred to adult stem cells:

Moderator: But what could be the reason that they do obtain stem cells from embryos too? Someone: Money.

Evelyn: Yes, and there are mothers who say, alright, so if there weren't such poor places, where people are starving, where there is no water, clean water, if that didn't exist then probably no woman in her right mind would allow anyone to touch her embryo. (Group 5)

Participants were also asked whether they had heard about controversies surrounding embryonic stem cell research. Only a few reported hearing anything about it. Of those few participants who remembered hearing about embryonic stem cell research at all, most did connect it to ethical/religious issues and debate - in some cases this was the only thing they could recall linked to it.

Moderator: But what you didn't say, another source of stem cells is the embryo. I don't know whether you've heard of that?

Miles: That's the research they don't support. Or it's the kind of stem cell research that gives rise to such counter-arguments and hostility. (Group 7) 
But recollections of even these few people about controversy remained vague, for example, they were not able to pin down key players of the debate. They did not know who spoke up for or against it. The lack of knowledge about the controversy was so great that even when presented with photos of key players of the foreign debate no recollections surfaced.

\section{Sources of information}

Topics can differ in the degree to which people get their information from personal experience and everyday discussions and because of this the role of the media can be different. Hardly any ordinary member of the Hungarian public has direct personal experience with stem cell research (for example donating embryos for stem cell research is not possible in Hungary). At the same time some people (even if it is only a small minority) can have direct personal experience with stem cell treatments, the harvesting of stem cells from umbilical cord blood, and stem cell capsules.

As personal experience is basically non-existent regarding stem cell research, two other main possibilities remain for people: hearing about it from the media (we include under media reading about it on the internet), and hearing about it from other people. Topics might differ also in the degree to which people discuss it among themselves. If - as we suppose - it indeed turns out that stem cell research is not a topic which is talked about in everyday conversations, that indicates that the role of the media in furnishing the public with information on this issue is of primary importance.

Throughout the discussions on associations and knowledge of stem cell research, the media was often referred to spontaneously by the participants. 
Anna: I first heard about it on TV, that in childhood, they take out this or that, something from someone and store it, and they can use it later for therapy. I heard something like that about it. (Group 4)

Violet: I saw it too on TV, they take it from the umbilical cord and store it. (Group 4)

Victoria: A good while ago I read an article, stem cells weren't such a fashion then in Hungary, and... that someone had to go to China to have that treatment. (Group 5)

When the participants were asked for information about what they knew about stem cells or stem cell research, they often referred to media reports, with some explicitly stating that they only knew what they had seen in the media (this included media outlets via the internet, only a few people recalled actively searching for information on stem cells). Even though it was expressed in some groups that there was not much in the media about stem cell research, all participants identified the media as their major source of information on this issue.

Although the media provided the main resources about the topic for the participants, often information remembered from the media was very vague, without concrete cases and details, rather just typical elements of new stories were remembered. Some participants had problems recalling whether what they remember seeing in the media was related to stem cells or some similar topic.

Lily: Well, it's all blurred now, whether it was exactly about cloning or some other medical thing like that. All I can say is approximately what Chloe said, I remember the same general scheme, you get the news that they have discovered something good. (Group 1)

A few people mentioned in the groups that they were interested in scientific news. These people knew more about the topic, and consumed more media on these topics. Some of them mentioned watching documentaries on topics related to stem cells. Particular personal motivation was also related to media consumption. 
There were only a few people who actively searched the internet for writings connected to stem cells. And proactive information seeking was linked to particular personal motivation: looking for information on stem cell banks as a relative wanted to have stem cells taken from the umbilical cord, looking for information because the participant wanted to take stem cell capsules or was involved/asked to be involved in selling stem cell capsules.

Evelyn: I looked into it, in my family my sister had a son last year and they took stem cells from his and they are frozen. Specifically I was looking for where it is done and how much it costs. (Group 5)

Most participants did not express interest in scientific topics. Some mentioned that even if stem cells were discussed in the media, they did not pay too much attention. Reasons given for the lack of interest included: that they are not affected personally, it is too utopist/out of reach, not part of their lives (or the lives of average Hungarians) in the near future, or just plain lack of interest in scientific topics. This lack of interest /attention limited the degree to which the media could resource their knowledge. This lack of interest was even present in the group of sociology students: they framed stem cell research mainly as a medical/scientific issue and they did not see the relevance of the social implications of such research.

The media also resourced the discussion in such a way that participants built logical assumptions based on the elements they saw in the media linked to stem cells. Logical inferences were sometimes also made based on media presentation of phenomena other than stem cell research.

Just because a certain percent of the media coverage discusses a topic it does not necessarily mean the audience paid attention to that news item or read that article. Thus, in the investigation of the role of the media it is important to examine what people's perception is towards what the media has shown (Lupton and Tulloch 2001). When studying the media 
perception of the focus group participants we found that typical media reports on stem cell research/treatments were identified in most groups to be of two kinds: a. a Hungarian patient who wants to got abroad for expensive treatment involving stem cells, b. news bulletins presenting advances in stem cell research, advances typically achieved by foreign researchers. This basically echoed the two dominant categories that we had found in the analysis of the media coverage.

Olivia: In the meantime it's occurred to me that really, it was discussed in a lot of newspaper advertisements, and programs like Aktív, that a young child was sick and the family couldn't afford to have it treated and they had to pay millions of forints and have sold everything they own and want to go out to, say, China. And that's somehow good that it drew our attention to the fact that there is such a method, and we really should be socially sensitive, and really there is a young girl or boy who is sick, but once again they were really trying to get money out of people, and we really didn't know what it is. So they really didn't say anything concrete about what this means and what the methods are.(Group 1)

Thomas: I think there was once a news item that they announced by saying: breakthrough in medicine, because even incurable diseases can be healed with stem cell research... (Group 5)

According to the participants' perception the media did not construct stem cell research as a political or controversial issue. Media perception related to stem cell research was not focused on famous people, or on any significant key events, or any key visual images - in contrast to the UK groups.

In most groups fiction was not referred to in the discussions spontaneously. However, the sociology students mentioned films many times, and there were two participants in another group that sometimes referred to fiction.

For most participants the media was the sole information source on stem cell research and related issues. However, some individuals, besides identifying the media as their primary information source, mentioned other secondary sources of information: acquaintances; lecture 
and brochures on nutritional supplements, which included stem cell capsules; a brochure which advertised taking stem cells from the umbilical cord, school; seeing a sign in a hospital on stem cell treatment. These secondary information sources mainly informed participants about stem cell treatment/storage, but not stem cell research as such.

It seems that stem cells are not a topic that people discuss among themselves if there is no personal connection involved for at least one of the parties (personal connection being either receiving/needing stem cell treatment, or selling stem cell capsules, stem cells being taken from umbilical cord). At least in the groups, in all of the cases where participants mentioned hearing some information about stem cells from another person, a personal connection could be established for at least one of the parties.

\section{Summary and conclusion}

One of our goals with our focus group sampling strategy was to explore diversity. However, in spite of the diversity of the sample, spontaneous discourse about stem cell research - i.e. discourse before the moderator introduced the topic of embryos into the discussions -was remarkably homogeneous. Stem cell research/treatments were framed in terms of medical results/cures and human interest stories - echoing the two dominant categories of story from the Hungarian press. Several possible framings of stem cell research were missing from the discourse in the focus groups. The embryo was absent from this discourse, as well as issues connected to it. Frames of understanding the topic were non-political and non-controversial similarly to the dominant presentation of the media.

The extent to which the two typical types of articles - breakthrough and human interest stories - could resource knowledge on stem cells is limited. Participants' accounts 
indicate that the human interest stories did engage some people emotionally (even if for some there were ambivalent emotions as they were sorry for the child, but irritated at the pleas for money). However, we found these articles had a low amount of information linked to stem cells, as their focus was more on the drama of the family, on the fund raising. Participants also commented that it was the patient's personal drama which engaged them and not the scientific aspects of the article. Articles of the scientific breakthrough frame contained a relatively high amount of information on stem cells (especially in the case of the political newspapers), but they might be less accessible and engaging for the readers than writings belonging to the human interest story frame. Some people might not be interested in scientific news, and so do not read these types of articles. In fact, some focus group participants did comment that they were not interested in scientific news, did not pay attention to such items, and that these kinds of news bulletins were hard to understand. It is also relevant however, that in a relatively large portion of cases scientific breakthrough articles mentioned in their titles the medical conditions that stem cells can cure. If a concrete illness was not mentioned, in many cases at least some reference was made to healing. Hence, even if someone only glanced at the titles of these texts, he/she did not have to read the whole article to get minimal information suggesting the benefits (and if TV news bulletins were organized similarly with the emphasis on the benefit, then even someone not paying close attention to scientific news bulletins might still recall later some minimal information on benefits). It is relevant to note that both dominant categories of stories gave the strong message that stem cells equal cures.

Nowadays approaches assuming a minimal influence of the media are popular among some scholars (Bajomi-Lázár 2006, Katz et al. 1974, Petts et al. 2001). Other scholars have drawn attention to the fact that active interpretation by the audience can have its limits (Kitzinger 1999). In the case of complex scientific topics, for example, lack of personal experience or intellectual resources might constrain the freedom of interpretation. Our results 
illustrate the argument that the role of the media cannot always be considered negligible. We found in our groups that participants did not question the truth of anything that they heard about in the media on stem cells while the media was the primary - for many people the exclusive - source of information ${ }^{11}$. Moreover, framing amongst the audience members resembled the dominant framing in the press (non-controversial, with embryo missing). Information is related to attitude formation. If the media does not give information on embryonic stem cell research in such a way that people consuming the media afterwards remember this information, people might not be aware of this phenomenon, thus they are not in a position to build attitudes towards it, as they do not even register that it exists. That, we argue, is also an important media effect, not a minimal one.

In our research we found a relationship between gaps in knowledge/associations of focus group members and media coverage. If we trace back those issues which were gaps in knowledge/associations in the focus group discussions and look at their press representation, we find that all of these had minimal, or at least only small media coverage. Also, these rare pieces of information almost exclusively appeared in hard news and predominantly in the political papers.

If we approach the issue from the other way around, from the press coverage, and look at the issues that were present only to a small/minimal degree or even absent from the press articles and check whether these appeared in the focus group discussions we find that these issues were often but not always missing from the focus group discussions. Cases where something was discussed in the focus groups even if it was only a minor/marginalized topic within the press, included discussion on the sources of stem cells. While the embryo, umbilical cord, and bone marrow were each mentioned explicitly as a source in less than one seventh of the articles, the latter two sources were part of the associations of the focus group participants. Our argument is that even though these three sources of stem cells were all 
discussed in a similarly small proportion of articles, articles on the embryo were presented in a way which engaged the audience less and appeared mainly in outlets which reached only a segment of the population. Another cause for the difference could also be that umbilical cord and bone marrow could be more a subject of interpersonal communication, as with these there may be some people who have personal experiences, and as we saw in our focus groups: participants did not talk of stem cells in their everyday life unless there was a personal connection in the case of one of the participants. It is also relevant that we only studied a segment of the media for a certain time period. We assume that media attention to the umbilical cord was higher earlier, for example when there was a debate in the Hungarian press on the umbilical cord stem cell banks. Other kinds of press outlets, for example women's magazines, potentially also might have more articles on umbilical cord stem cells. We did not analyze advertisements - such as for stem cell banks - while these can also inform the public of umbilical cord stem cells.

Comparing the results of the Hungarian and the UK research (Hughes et al. 2008, Kitzinger 2008a) it can be stated that notwithstanding some similarities, research subjects of the two countries framed stem cell research differently in many respects. The similarities and differences in the discourses of the focus groups of the two countries often echoed the similarities and differences between the media coverage. For example controversies surrounding embryonic stem cell research appeared more in the UK media, while they were relatively neglected in the Hungarian media. At the same time while UK participants often mentioned these controversies and key famous characters in the debate, this was absent from spontaneous discourse in the Hungarian focus groups, and when prompted only a few participants had vague and minimal knowledge of the controversies.

There are severe limitations to generalizing focus group data beyond the concrete contexts in which they were generated (Vicsek 2010). However, the fact that in both countries 
the focus group samples were quite diverse, and in spite of this within each country many aspects of the discussions were homogeneous, suggests that our findings might have relevance beyond their particular locations ${ }^{12}$.

\section{Acknowledgments}

The author would like to express gratitude to Jenny Kitzinger for the help she provided throughout the research and for her insightful comments on earlier versions of this paper. The research was funded by the Hungarian Scientific Research Fund (OTKA), and Lilla Vicsek was supported in her work by the Hungarian Academy of Sciences with a Bolyai János Grant.

\section{NOTES ON CONTRIBUTORS}

Lilla Vicsek, Ph.D. is Assistant Professor at the Institute of Sociology and Social Policy at Corvinus University of Budapest. She has more than a decade of experience in focus group research, conducting and analysing groups on diverse topics. She has written a book on the method and expounded her view in several articles. Her other strand of research has focused on representation in the media and media influence. She is currently conducting research on audience perception of genetically modified crops and media representation of GMO in the Hungarian press. She is also investigating how the media framed the so-called "stem cell scandal" in Hungary in July-August 2009.

Júlia Gergely is a Ph.D. student at the Corvinus University of Budapest. She is currently doing research on segregation in Budapest and its agglomeration.

\section{Endnotes}




\section{References}

2006. évi XCVII. törvénnyel módosított 1997. évi CLIV tv. az egészségügyről [Act CLIV of 1997 on Public Health amended by Act XCVII of 2006] [online]. Available from:

http://net.jogtar.hu/jr/gen/hjegy doc.cgi?docid=99700154.TV [Accessed 24 May 2009].

Augoustinos, M., Russin, A. and LeCouteur, A., 2009. Representations of the stem-cell

cloning fraud: from scientific breakthrough to managing the stake and interest of science.

Public Understanding of Science, 18(6), 687-703.

Bajomi-Lázár, P., 2006. Manipulál-e a média? [Does the media manipulate?]. Médiakutató, (2), 56-85.

Checar, C. K. and Kitzinger, J., 2007. Science, patriotism and discourses of nation and culture: reflections on the South Korean stem cell breakthroughs and scandals. New Genetics and Society, 26(3), 289-307.

Glasner, P., 2005. Banking on Immortality? Exploring the Stem Cell Supply Chain from Embryo to Therapeutic Application. Current Sociology, 53(2), 355-366.

Hegedűs, R., 2007. Újabb adatok a magyar „egyházias vallásosság” társadalmi megjelenéséröl [Recent data on the social appearance of Hungarian "church religiousness"]. In: R. Hegedűs and E. Révay,eds. Úton. Tanulmányok Tomka Miklós tiszteletére Szeged: Szegedi Tudományegyetem Vallástudományi Tanszék, 283-296.

Henderson, L. and Kitzinger, J., 1999. The human drama of genetics: 'hard' and 'soft' media representations of inherited breast cancer. Sociology of Health \& Illness, 21(5), 560-578. Hughes, E., Kitzinger, J. and Murdock, G., 2008. Media Discourses and Framing of Risk. Working Paper 27 [online]. Available from http://www.cardiff.ac.uk/jomec/resources/KitzingerWkPaper27.pdf [Accessed: 8.12.2009.]. 
Jurberg, C., Verjovsky, M., de Oliveira Cardoso Machado, G. and Rodrigues, A. M., 2009. Embryonic stem cell: A climax in the reign of the Brazilian media. Public Understanding of Science, 18(6), 719-729.

Karácsony, G., 2001. Értékek és választások [Values and choices]. Educatio, (3), 504-516.

Katz, E., Blumler, J. G. and Gurevitch, M., 1974. Utilization of mass communication by the individual. In: J. G. Blumler and E. Katz,eds. The uses of mass communication. Beverly Hills, CA: Sage, 19-32.

Kitzinger, J., 2008a. A Basic Overview of Findings from Focus Groups about Stem Cell Research. Cardiff, Manuscript.

Kitzinger, J., 2008b. Questioning Hype, Rescuing Hope? The Hwang stem cells scandal and the reassertion of hopeful horizons. Science as Culture, 17(4), 417-434.

Kitzinger, J. and Williams, C., 2005. Forecasting science futures: Legitimising hope and calming fears in the embryo stem cell debate. Social Science \& Medicine, 61(3), 731-740. Lupton, D. and Tulloch, J., 2001. Risk, the mass media and personal biography. European Journal of Cultural Studies, 4(1), 5-27.

Nisbet, M., Brossard, D. and Kroepsch, A., 2003. Framing science - The stem cell controversy in an age of press/politics. Harvard International Journal of Press-Politics, 8(2), $36-70$.

Petts, J., Horlick-Jones, T. and Murdock, G., 2001. Social ampification of risk: The media and the public. Contact Research Report. Sudbury: HSE Books.

Prainsack, B., 2006. 'Negotiating life': The regulation of human cloning and embryonic stem cell research in Israel. Social Studies of Science, 36(2), 173-205.

Reis, P., 2008. How Brazilian and North American Newspapers Frame the Stem Cell Research Debate. Science Communication, 29(3), 316-334. 
Tomka, M., 1996. Vallás és vallásosság [Religion and religousness]. In: R. Andorka, T. Kolosi and G. Vukovich,eds. Társadalmi riport 1996 [Social Report 1996]. Budapest: Tárki, $592-616$.

Vicsek, L., 2004. Bizonytalanságérzet a mai Magyarországon - Egy fókuszcsoportos vizsgálat eredményei. [Feeling of insecurity in Hungary today - Findings of a focus group study]. Társadalomkutatás, 22(2-3), 279-313.

Vicsek, L., 2010. Issues in the Analysis of Focus Groups: Generalisability, Quantifiability, Treatment of Context and Quotations. The Qualitative Report, 15(1), 122-141. Available from: from http://www.nova.edu/ssss/QR/QR15-1/vicsek.pdf.24.2.2010.

Weingart, P., Salzmann, C. and Wormann, S., 2008. The social embedding of biomedicine: an analysis of German media debates 1995-2004. Public Understanding of Science, 17(3), 381396.

Williams, C., Kitzinger, J. and Henderson, L., 2003. Envisaging the embryo in stem cell research: rhetorical strategies and media reporting of the ethical debates. Sociology of Health \& Illness, 25(7), 793-814. 


\title{
Tables
}

Table 1. Variables in the quantitative content analysis

\begin{abstract}
DOMINANT STEM CELL THEME: The dominant theme linked to stem cells was coded for each article ${ }^{13}$. Original categories of the variable were decided based on the literature and on a pilot coding of the articles: 1. Human interest story on drama of one or a few non-famous patients, 2 . Scientific result, breakthrough, overview of the state of the art of research, 3. Political/ethical controversy linked to stem cell research, someone taking a stand on stem cell research, 4. Opening/construction of an institution which deals with stem cell research, stem cell treatment, 5. Legal battles and controversy surrounding the stem cell capsule developed in Hungary, 6. Celebrity related non-political news - such as a star having stem cells taken from umbilical cord, ill celebrity, star taking stem cell capsules, etc., 7. Legislation, regulations in relation to stem cells, 99. Other nonfrequent topics. If any new topic emerged during the coding process, it was recorded what precisely the topic was, and if a certain topic came up on more than one occasion new categories were created. Three categories that were created in this way: 8. Stem cells in the arts (for e.g. an art object that had stem cells on it as a theme), 9. Sport related news, 10. Stem cell related program.
\end{abstract}

SOFT AND HARD NEWS: Based on the topic of the whole article (not just the stem cell part): 1. dominantly soft news: human interest stories (such as drama of individual people or nonpolitical stories about celebrities), 2. dominantly hard news: scientific and political topics, 3. mixed, with neither dominating, 4 . could not be determined.

KIND OF PAPER: 1. tabloid (Bors, Blikk), 2. political paper (Népszabadság, Magyar Nemzet).

\section{TIME OF APPEARANCE OF THE ARTICLE}

FRONT PAGE: 1. Article did not appear on front page, 2. article appeared on front page.

LENGTH OF THE STEM CELL RELATED PART OF THE ARTICLE: 1 . Maximum one sentence, 2. More than one sentence.

HUNGARIAN RELEVANCE: 1. no Hungarian relevance, 2. article contained Hungarian relevance (Hungarian person, organization, location was mentioned in the article).

SOURCE OF STEM CELLS: 1. not mentioned in the article, 2. explicitly mentioned in the article.

BONE MARROW AS SOURCE: 1. bone marrow was not mentioned, 2. bone marrow was mentioned explicitly as a source of stem cells. Similar variables were created for embryo, blood, skin, and fetus. An extra variable was also created for whether embryonic stem cell research was mentioned in the article.

VARIABLES ON THE INFORMATION IN THE ARTICLES: Variables were created where we checked whether: 1. a piece of information was not mentioned in an article at all, or 2. piece of information was mentioned in the article. The kinds of information we looked for: any relationship between cloning and stem cells; regulation, legislation connected to embryonic stem cell research; death of embryo mentioned at extraction of stem cells; sources of embryos mentioned; cloned embryos mentioned as source; IVF embryos mentioned as source; age of embryo mentioned at extraction of stem cells. Separate variables were created for all these kinds of information.

Table 2. Composition of the focus groups

\begin{tabular}{|l|l|}
\hline 1 & Sociology BA students at a prestigious university \\
\hline 2 & Members of a pensioners' club \\
\hline 3 & $\begin{array}{l}\text { Students at a secondary school (studying to be car mechanics, studying } \\
\text { marketing, hospitality) }\end{array}$ \\
\hline 4 & $\begin{array}{l}\text { Lower-class middle-aged people (unemployed people taking part in a } \\
\text { vocational course and people with low-status jobs - all with a low level }\end{array}$ \\
\hline
\end{tabular}




\begin{tabular}{|l|l|}
\hline & of education) \\
\hline 5 & Diverse group A \\
\hline 6 & Diverse group B \\
\hline 7 & Diverse group C \\
\hline
\end{tabular}

Table 3. Information on stem cells in the articles

\begin{tabular}{|lll|} 
& & \\
\hline The capacity of stem cells to develop into other type cells & 33 & 10.1 \\
Any relationship between cloning and stem cells & 24 & 7.4 \\
Regulation, legislation connected to embryonic stem cell research & 20 & 6.1 \\
Death of embryo mentioned at extraction of stem cells & 17 & 5.2 \\
Sources of embryos mentioned & 13 & 4.0 \\
Cloned embryos mentioned as source & 6 & 1.8 \\
IVF embryos mentioned as source & 10 & 3.1 \\
Age of embryo mentioned at extraction of stem cells & 8 & 2.5 \\
\hline
\end{tabular}

$\mathrm{N}=326$ 


\section{Endnotes}

${ }^{1}$ Some of these discussed the debate on the usage of the embryos, others focused on the scandal surrounding Professor Hwang, who was doing embryonic stem cell research.

${ }^{2}$ Interviews were conducted with Dr. Balázs Sarkadi and Dr. Judit Cserepes. Dr. Balázs Sarkadi is a member of the Hungarian Academy of Sciences, is chairman of the Stem Cell Committee of the Medical Research Council in Hungary, and leads research projects on stem cell research. Dr. Judit Cserepes, physician and economist, conducts stem cell research, and is an expert on Hungarian stem cell regulation. We also consulted István Balsai, a Member of the Parliament (Fidesz - Hungarian Civic Union) on the political context, Dr. Béla Somfai, Professor at the Theological College of Szeged on the religious context, and Tímea Bagó, a district nurse, on the marketing of stem cell banks reaching pregnant women.

${ }^{3}$ Throughout the press analysis we refer to our research material as a sample, however it is not a sample in the statistical sense, it is rather a population, as it contains all the articles that appeared in the papers investigated in the period examined that contained the expression stem cell or its variations. Articles were obtained from the electronic database of Observer Budapest Médiafigyelö Kft. There were two tabloids investigated: Blikk, Bors (earlier name Színes Bulvár Lap), and two political papers:

Népszabadság (Left-wing, liberal in its political orientation) and Magyar Nemzet (Right-wing, conservative orientation). A daily on sports (Nemzeti Sport) was included in the sample as it is among the most widely read papers and as it had a few articles dealing with the topic. We did not include the widely-read, but free newspaper, Metropol in the sample.

${ }^{4}$ The coders were two students at the Corvinus University of Budapest: Júlia Honfi and Marcell Márkus.

${ }^{5}$ According to church expert Béla Somfai and stem cell experts Judit Cserepes and Balázs Sarkadi.

${ }^{6}$ At the time of the research the parliamentary parties were: Hungarian Socialist Party (MSZP), Alliance of Free Democrats (SZDSZ), Hungarian Democratic Forum (MDF), Fidesz - Hungarian Civic Union (FIDESZ - Magyar Polgári Szövetség), Christian Democratic People's Party (KNDP). The web-sites checked on April 15, 2009 were: www.mszp.hu, www.szdsz.hu, www.fidesz.hu, www.mdf.hu, www.kdnp.hu. The home-page of Fidesz contained articles selected from the press on stem cell related information (as this web-site has selected articles on a variety of topics), but even on this web-site no viewpoint of the party was presented.

${ }^{7}$ The position of the Hungarian Competition Authority can be found at: http://www.gvh.hu/gvh/alpha?null\&m5 doc=5389\&pg=72 [Accessed 18 May 2009].

${ }^{8}$ According to expert Judit Cserepes and a representative from Humancell Umbilical Cordblood Stem Cell Bank.

${ }^{9}$ Only those sources are presented in the diagram which were present in at least 1.5 percent of the sample.

${ }^{10}$ In the interpretation of the above data on sources it is also important to take into account that a source was only coded if there was explicit mention in the article that it was a source of stem cells. There were several articles on stem cell treatments where bone marrow was mentioned, but it was not stated that it was a source of stem cells. These were not coded under the category bone marrow. There were also articles which contained the expression 'embryonic stem cell research' without making mention of the fact that this involved stem cells taken from embryos. These were not coded under the category of embryo as source. If we create a different classification, a broader category, and group together the articles which make any mention of the embryo or embryonic stem cell research, then this category makes up 19 percent of the articles - this is still a minority of the articles, and still less then what was written about adult stem cells. The nature of coverage of these articles touching on this broader category of embryonic stem cell research was similar to the nature of coverage of the articles which explicitly referred to embryo as source.

${ }^{11}$ This is similar to what Kitzinger (2008a) found in the UK focus groups. The media were a primary source and although there was general criticism in some cases of the media coverage, concrete media information was never questioned.

${ }^{12}$ Besides the media influence, the different context of the two countries also has to be taken into account in the interpretation of the results. For example, while in the UK there is embryonic stem cell research conducted at research centers and even research on cloned embryos is allowed, in Hungary at the time of the research there was only one research center where embryonic stem cell research was done, and even this - because of the Hungarian legislative background - used stem cell lines originating from outside Hungary. It is also relevant that in Hungary there was no debate by political actors on embryonic stem cell research in the investigated period or before, in contrast to the UK.

${ }^{13}$ This was not the same as the dominant theme of the whole article in some cases, as there were articles in which stem cells was a minor topic. 